\title{
Preparation of Instant Tanier (Xanthosoma Sagittifolium) Flakes ${ }^{1}$
}

\author{
E.J.Rodríguez-Sosa and M. A. González²
}

ABSTRACT

Tanier (Xanthosoma sp.) dehydrated instant flakes were prepared from the white-fleshed cultivar locally known as Rascana. The instant flakes prepared as meat pie (pastelón) and as forcemeat (rellenos) were taste evaluated and found acceptable by a panel. Pasting properties of slurries prepared from the instant flakes and from a flour prepared by sifting the flakes through a 0.840 $\mathrm{mm}$ screen in a Homoloid mill were examined using the Brabender Amylograph-Viscograph. Flour had higher viscosity. Cooking to $93 \mathrm{C}$ produced no peak viscosity, indicating that tanier starch in flakes and flour is not fragile.

\section{INTRODUCTION}

Tanier (Xanthosoma sp.) is a starchy root crop indigenous to the West Indies (3). It is grown throughout the tropics for its edible tuber.

In Puerto Rico tanier is usually eaten boiled. Generally it is grown by small farmers in the highlands of the central part of the island. Its production totaled 265,000 cwt in $1973-74$ with a farm value of $\$ 4.31$ million. In the same period 83,677 cwt were imported.

As with other tropical crops, no methods have been developed for storing tanier for extended periods. It can be stored satisfactorily for several weeks at ambient conditions. Lately, tanier has been sold frozen in wax velvet boxes, an expensive means of preservation.

Methods of preparing instant mashed white potatoes (4), sweet potatoes (2), and yams (Dioscorea spp.) (4) are reported in the literature.

Starch provides many desirable as well as undesirable properties to foods. The Brabender Amylograph-Viscograph ${ }^{3}$ has been the instrument used most extensively to measure the changes in viscosity or consistency which occur when heating, cooking, and cooling starch solutions as well as starchy flour slurries. The effect of flake size and precooking on pasting characteristics of yam instant flakes was studied by RodríguezSosa and González (5), and by Rodríguez-Sosa et al. (6).

Purpose of this study was to prepare instant mashed tanier of good quality and acceptance, thus increasing throughout the year availabil-

' Manuscript submitted to Editorial Board January 26, 1976.

${ }^{2}$ Assistant Food Technologist and Technical Director, respectively, Food Technology Laboratory, Agricultural Experiment Station, Mayagüez Campus, University of Puerto Rico, Río Piedras, P.R.

3 Trade names are used in this publication solely for the purpose of providing specific information. Mention of trade names does not constitute a guarantee or warranty of equipment or materials by the Agricultural Experiment Station of the University of Puerto Rico or an endorsement over other equipment or materials not mentioned. 
ity of tanier in a form which might be practical for consumers and industrial users, and possibly as an inexpensive means of storing tanier.

\section{MATERIALS AND METHODS}

The study used commercial samples of the white fleshed cultivar locally known as Rascana.

Instant flakes were prepared as follows: Tubers were washed, lyepeeled in a $15 \% \mathrm{NaOH}$ solution at $200^{\circ} \mathrm{F}\left(93.3^{\circ} \mathrm{C}\right)$ for $6 \mathrm{~min}$, brushed in a rotary washer provided with water jets, trimmed, sliced into about $1 / 2$ in slabs, and soaked for $4 \mathrm{~min}$ in a $0.6 \%$ potassium metaisisulfite solution to inhibit browning reactions. Slabs were steam cooked for 15, 20, 25, and $30 \mathrm{~min}$. Samples were identified by cooking times. Cooked slabs were ground and mashed in a Hobart machine with addition of water to adjust total solids to about 20\%. During mashing mono- and di-glycerides (Atmul 84) were added at a $0.5 \%$ level based on the total solids content.

The mashed tanier was dehydrated in a steam-heated double drum dryer with a steam pressure of $60 \mathrm{lbs} / \mathrm{in}^{2}$. Drum speed was adjusted between 1.5 to $2.0 \mathrm{r} / \mathrm{min}$ with a clearance between drums of about 0.008 in. Antioxidants (BHA, BHT in 1:1 ratio) were added to the flakes at 50 $\mathrm{p} / \mathrm{m}$. Samples were packed in No. 303 tin cans and stored at ambient conditions.

Samples at different processing stages were analyzed for total solids. Transversal thin slices were cut from the center of the tuber and diced into small cubes to facilitate moisture evaporation. Around $2 \mathrm{~g}$ were weighed in an analytical balance and dehydrated in a vacuum oven at $50^{\circ} \mathrm{C}$ for $24 \mathrm{~h}$. Total solids were obtained by subtracting moisture loss from total weight of sample.

The instant flakes were divided into two portions. One was ground in a Homoloid mill using a $0.840 \mathrm{~mm}$ screen; the other was sifted through an $8.00 \mathrm{~mm}$ screen and the flakes retained in a $2.38 \mathrm{~mm}$ screen were saved. Slurries of the instant flour and flakes were prepared to measure viscosity, using the Brabender Amylograph-Viscograph. Slurries were prepared by mixing $70 \mathrm{~g}$ of flakes or $50 \mathrm{~g}$ of flour with $450 \mathrm{ml}$ distilled water in a Waring blender at moderate speed for $30 \mathrm{~s}$. The Amylograph was set at $75 \mathrm{r} / \mathrm{min}$ and the $700 \mathrm{~cm} / \mathrm{g}$ cartridge was used. The initial viscosity of the slurries was determined at room temperature $\left( \pm 27^{\circ} \mathrm{C}\right)$. The instrument was then set at $30^{\circ} \mathrm{C}$ and the heating-cooling cycle initiated. Temperature was increased at $1.5^{\circ} \mathrm{C} / \mathrm{min}$ up to $93^{\circ} \mathrm{C}$ and held constant for $1 \mathrm{~h}$. Samples were then cooled at the same rate to $50^{\circ} \mathrm{C}$ and held at that temperature for another hour.

Instant tanier flakes prepared as meat pie (pastelón) using corned beef, and as forcemeat (rellenos) using ground beef were taste evalu- 
ated. The flakes were reconstituted with water at $180^{\circ} \mathrm{F}$. Beaten eggs were added to improve binding properties. The meat pie was baked at $375^{\circ} \mathrm{F}$ for $30 \mathrm{~min}$ and the forcemeat fried in vegetable oil. They were evaluated for appearance, flavor, texture, and overall acceptability. The meat pie overall acceptability was determined using a \pm 2 scale ranging from very acceptable $(+2)$ to not acceptable $(-2)$. A 6-point hedonic scale ranging from "like very much" (6 points) to "dislike" ( 1 point) was used for all other evaluations.

TABLE 1.-Pilot plant processing yields of prepared instant tanier flakes

\begin{tabular}{lcccc}
\hline \multirow{2}{*}{\multicolumn{1}{c}{ Processing stages }} & \multicolumn{4}{c}{$\begin{array}{c}\text { Weight of materials at given } \\
\text { cooking time (min)- }\end{array}$} \\
\cline { 2 - 5 } & 15 & 20 & 25 & 30 \\
\hline Fresh tanier & $L b$ & $L b$ & $L b$ & $L b$ \\
Peeled tanier & 30 & 30 & 30 & 30 \\
Cooked tanier & 21 & 20.5 & 22 & 21.5 \\
Trimmings & 24.5 & 20 & 21.75 & 21.75 \\
Peel & 1 & .75 & .5 & 1 \\
Water added during mashing & 8 & 8.75 & 7.5 & 7.5 \\
Instant flakes & 10 & 12 & 10 & 12 \\
\hline
\end{tabular}

TABLE 2.-Total solids of tanier at various processing stages

\begin{tabular}{lcccc}
\hline \multirow{2}{*}{ Processing stages } & \multicolumn{4}{c}{ Total solids at given cooking time (min) - } \\
\cline { 2 - 5 } & 15 & 20 & 25 & 30 \\
\hline Fresh & $\%$ & $\%$ & $\%$ & $\%$ \\
Cooked & 37.95 & 38.56 & 35.49 & 35.12 \\
Before dehydration & 30.07 & 28.20 & 41.63 & 36.89 \\
Instant flakes & 22.37 & 21.74 & 22.86 & 22.44 \\
\hline
\end{tabular}

\section{RESULTS AND DISCUSSION}

Table 1 shows yields of instant tanier flakes after processing. The average batch weight after lye-peeling was $21.25 \mathrm{lb}$, a $30 \%$ weight loss, of which about $26 \%$ was peel. The average yield of instant flakes was 6.5 lb, or $21.7 \%$.

Table 2 shows total solids of tanier taken at various processing stages. It is generally recognized that proximate composition and other properties of plant materials frequently vary with changes in growing conditions. Because commercial samples were used in these experiments, differences in analyses among samples might be attributed to differences in raw materials. Total solids of samples cooked for 15 and $20 \mathrm{~min}$ were lower than those of fresh tanier; in samples cooked for 25 and 30 min it was the opposite. Although results for samples cooked for $25 \mathrm{~min}$ were extremely high, the tendency could be due to some dehydration of 
the slabs during cooling prior to the analysis. In longer steam cooking periods, slabs attained higher temperature; this might contribute to evaporation of surface and free water in cells.

A portion of flakes was ground to $0.840 \mathrm{~mm}$ mesh to study the effect of particle size on pasting properties. The flour used for the slurries was reduced from $70 \mathrm{~g}$ in flakes to $50 \mathrm{~g}$ in flour so that pasting measurements could be recorded on the chart. As expected, pasting temperatures were lower, while the other amylographic measurements were higher for instant flour (table 3).

Figure 1 shows typical amylograms of tanier instant flour and instant flakes. The ascending portion of the amylogram when heating to $93^{\circ} \mathrm{C}$

TABLE 3.-Pasting characteristics of tanier instant flakes and flour using the Brabender Amylograph-Viscograph

\begin{tabular}{|c|c|c|c|c|c|c|c|c|}
\hline \multirow{3}{*}{ Item } & \multicolumn{8}{|c|}{$\begin{array}{l}\text { Pasting characteristics at } \\
\text { given cooking times (min) - }\end{array}$} \\
\hline & \multicolumn{4}{|c|}{ Flakes } & \multicolumn{4}{|c|}{ Flour } \\
\hline & 15 & 20 & 25 & 30 & 15 & 20 & 25 & 30 \\
\hline Initial viscosity ${ }^{\prime}$ & 48 & 55 & 40 & 58 & 117 & 65 & 92 & 77 \\
\hline Pasting temperature $\left({ }^{\circ} \mathrm{C}\right)$ & 71 & 74 & 74 & 78 & 59 & 54 & 57 & 53 \\
\hline Viscosity at $93^{\circ} \mathrm{C}$ & 47 & 43 & 17 & 25 & 273 & 220 & 208 & 190 \\
\hline Viscosity after $1 \mathrm{~h}$ at $93^{\circ} \mathrm{C}$ & 107 & 85 & 67 & 92 & 148 & 195 & 128 & 165 \\
\hline Viscosity at $50^{\circ} \mathrm{C}$ & 292 & 238 & 182 & 265 & 403 & 380 & 327 & 377 \\
\hline Viscosity after $1 \mathrm{~h}$ at $50^{\circ} \mathrm{C}$ & 267 & 218 & 172 & 247 & 392 & 370 & 328 & 360 \\
\hline
\end{tabular}

${ }^{1}$ Viscosity is given in Brabender Units.

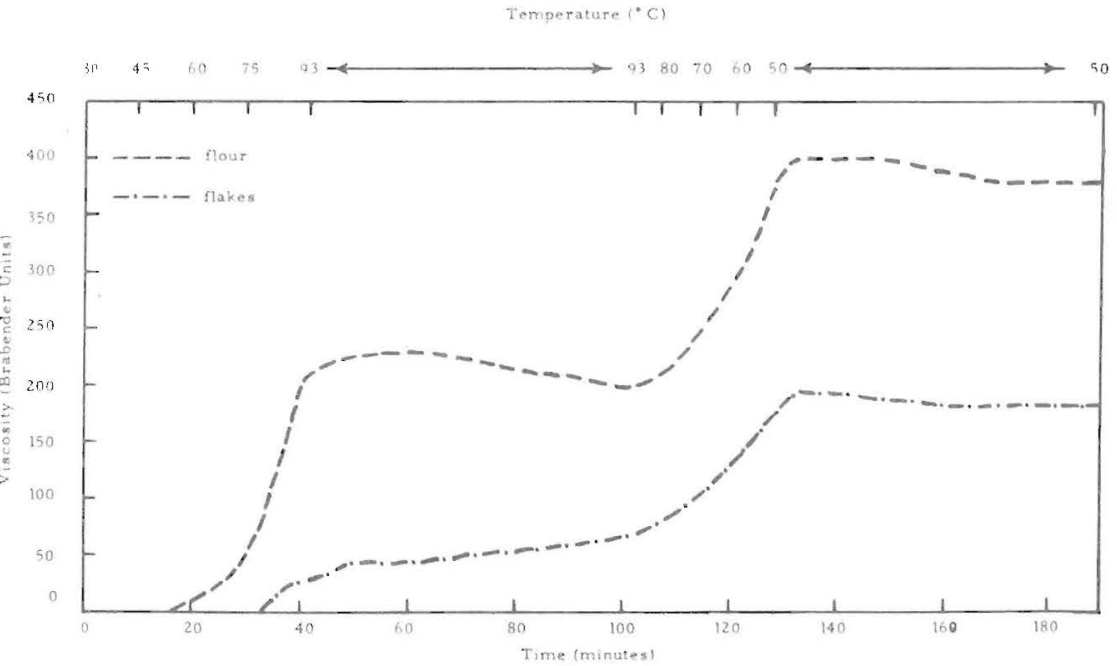

FIG. 1. - Typical amylograms of tanier instant flakes and flour of Rascana cultivar using the Brabender Amylograph-Viscograph. 
was sharper in flour. This is attributed mainly to the resistance of the swollen starch granules to displacement. No peak viscosity was observed in either case, reflecting the strength of tanier starch. In flakes, pasting increased during the cooking period at $93^{\circ} \mathrm{C}$, while in flour it decreased, that is, starch granules ruptured due both to overswelling and to mechanical disintegration caused by agitation of the starch paste. This probably occurred because more granule surface was exposed in the flour and consequently the opportunity to imbibe water and

TABLE 4.-Sensory evaluations of instant flakes prepared as meat pie (pastelón) and as forcemeat (rellenos)

\begin{tabular}{|c|c|c|c|c|}
\hline \multirow{2}{*}{ Cooking time } & \multicolumn{4}{|c|}{ Sensory scores' } \\
\hline & Appearance & Flavor & Texture & $\begin{array}{c}\text { Overall } \\
\text { acceptability }\end{array}$ \\
\hline \multicolumn{5}{|l|}{ Min } \\
\hline \multicolumn{5}{|c|}{ Pastelon } \\
\hline 15 & 4.7 & 5.0 & 5.1 & 1.0 \\
\hline 20 & 4.8 & 4.2 & 5.1 & 1.1 \\
\hline 25 & 4.8 & 4.8 & 5.0 & 1.1 \\
\hline 30 & 4.7 & 4.6 & 4.6 & .8 \\
\hline \multicolumn{5}{|c|}{ Rellenos } \\
\hline 15 & 5.0 & 5.1 & 5.1 & 5.1 \\
\hline 20 & 5.1 & 5.1 & 5.0 & 5.1 \\
\hline 25 & 5.2 & 5.2 & 5.3 & 5.3 \\
\hline
\end{tabular}

"Using a 6-point hedonic scale ranging from "Iike very much" (6 points) to "dislike" (1 point), except where indicated.

${ }^{2}$ Overall acceptability for pastelón was measured using a \pm 2 scale ranging from "very acceptable" $(+2)$ to "not acceptable" $(-2)$.

swell was greater. In the flakes, starch granules are closer and possibly the swelling capacity was restricted. This probably explains why they continued to swell while cooking at $93^{\circ} \mathrm{C}$ for 1 hour.

The reaggregation of starch molecules after slumries were cooled from $93^{\circ} \mathrm{C}$ to $50^{\circ} \mathrm{C}$ was greater in flour. A small thinning process occurred in the last cooking period, indicating that the starch in both flour and flake was stable at $50^{\circ} \mathrm{C}$.

Table 4 presents sensory scores of instant tanier flakes prepared as pastelon and as rellenos. All samples were found acceptable. The flour was not sensory-evaluated.

\section{RESUMEN}

Se prepararon hojuelas deshidratadas para restitución instantánea de yautía (Xanthosoma sp.) de la variedad de pulpa blanca conocida localmente por Rascana. Con las hojuelas se prepararon pastelón y rellenos de carne; ambos resultaron aceptables para. un panel de catadores.

También se examinaron las propiedades reológicas de las hojuelas y de una harina (tamiz de $0.840 \mathrm{~mm}$.) derivada de ellas. Se usó el amiloviscógrafo Brabender. La harina tuvo mayor viscosidad que las hojuelas instantáneas. Además se determinó que el almidón de yautía, tanto en la harina como en las hojuelas, no es frágil. 


\section{LITERATURE CITED}

1. Cording, J. Jr., and Willard, M. J. Jr., Drum drying of cooked mashed potatoes. U.S. Pat. 2, 759, 832, Aug. 21, 1956.

2. Deobald, J. J., McLemore, H. V., Roby, M. T., Peryam, D. R., and Heilgman, F., Precooked dehydrated sweet potatoe flakes, U.S. Dep. Agr., ARS-72-23:29 p.

3. Gooding, H. J., and Campbell, J. S., Preliminary trials of West Indian Xanthosoma cultivars, Trop. Agr., Trin., 38 (2): 145-52, 1961.

4. Rodriguez-Sosa, E. J., and González, M. A. Preparation of yam (Dioscorea alata L.) flakes, J. Agr. Univ. P.R., 56(1): 39-45 1972.

5. - Effect of flake size on pasting characteristics of instant Florido yam (Dioscorea alata) flake slurries, J. Agr. Univ. P.R., 58(2): 219-24, 1974.

6. - , and Parsi-Ros, O., Effect of precooking on the quality of instant flakes from Florido yam (Dioscorea alata L.) J. Agr. Univ. P.R. 58(3): 317-21, 1974. 